\title{
Cultivating Reasonableness in Future Citizens
}

\author{
Elizabeth Edenberg (Georgetown University)
}

\section{Civic Education and Respect}

Recent political discourse betrays a resurgence of overtly racist, sexist, and homophobic rhetoric in the public sphere. While these sentiments have always been with us, many hoped that the kinds of large public demonstrations led by neo-Nazis and the KKK were a thing of the past. It was largely assumed that modern progress gave rise to new and more cloaked forms of racism, sexism, and heterosexismtricky to put our fingers on and difficult to address insofar as the biases that worked to undermine political and social equality were often implicit. ${ }^{1}$ However, recent events have shown a significant and dangerous return to unapologetic expressions of racist, sexist, and homophobic rhetoric both online and on the streets. Whether these public expressions are manifesting long-held beliefs or whether the current context has fuelled new hatred, these actions are incompatible with equal respect for all people. ${ }^{2}$ Our society is in dire need of ways to combat these forms of inequality in order to cultivate a citizenry that has robust respect for all people as free and equal.

Politics is treated as a battleground between factions. But for citizens to cooperate with each other on fair terms, we must find ways to cultivate basic respect for each other. While there are many steps we can take as adults to try to understand the other side and engage in productive dialogue those with whom we disagree, I think one promising avenue for reform is to redesign civic education to explicitly teach children the skills needed to show equal respect across differences. Children's civic education should cultivate recognition respect for the freedom and equality of themselves and their fellow citizens - even in the face of deep disagreements. Recognition respect is a matter of giving due weight to a person's standing "to make claims and demands of [others] as equal, free and rational agents" (Darwall, 2006, p. 121). ${ }^{3}$ Teaching children to respect one another in the face of disagreement is one of the more important civic virtues of any political system that puts respect for persons at its core. Only when we are capable of equal respect for others will we have the hope of combating the vitriol so characteristic of contemporary political debate. In what follows I will outline Rawls's conception of reasonableness and show how cultivating the civic virtue of reasonableness could help children learn to respect their fellow citizens, even when they encounter people who are quite different from them. I will also consider some challenges to cultivating reasonableness in the age of Trump and suggest that, nevertheless, teaching children these civic virtues ought to be the goal of civic education.

\section{Cultivating the Civic Virtues of Reasonableness}

My own favoured approach to this problem is inspired by John Rawls's Political Liberalism. ${ }^{4}$ He drew our attention to the persistent problem of reasonable disagreement in politics. Given freedom of thought and conscience, disagreements about religion, morality, and the good life are likely to persist. This causes difficulties in offering a normative justification for any theory of justice or political authority meant to govern us all. Rawls drew an important distinction between reasonable pluralism and 'pluralism as such', arguing that a political conception of justice should be justifiable to all who qualify as reasonable.

The basic distinction lies in a moral qualification for reasonableness. ${ }^{5}$ He argues, "all reasonable doctrines affirm [...] equal basic rights and liberties for all citizens" (Rawls, 2005, pp. 482-483). Failing to recognize this basic free and equal status is unreasonable. This falls into the first of two basic aspects of reasonable persons: reasonable people seek terms of cooperation that are fair insofar as they protect each person's free and equal status (Rawls, 2005, pp. 4954). While there is a lot of room for disagreement on precisely what qualifies as treating someone as free and equal, I think certain basic components form a common core of respect. Recognition respect must involve a basic respect for the dignity of persons and their standing as an authoritative source of valid claims. This respect sets limits on permissible treatment of people. We can debate standards of dignity, equality, and freedom, but what is clear is that domination and subordination fail to meet the threshold of recognition respect for freedom and equality (Rawls, 2005, p. 446). ${ }^{6}$

It is by teaching children that political cooperation requires respecting the free and equal status of all of our fellow citizens that we might combat the racism, sexism, and heterosexism prevalent in public discourse in the age of Trump. Underlying these pernicious forms of unequal treatment is a failure of respect. Racism, sexism, heterosexism are all predicated on the belief (implicit or explicit) that skin colour, sex, gender, or sexual preferences should influence a person's social or political standing, available opportunities, and life prospects. Rather than learning to categorize people according to differences, children should learn respect for our common humanity. As a form of recognition respect, children must learn that one's standing as a person sets limits on permissible treatment. This may seem like a very simple step, but in our current 
unjust world, a basic form of equal respect would lead to enormous improvements in the lives of many.

The second basic aspect of reasonableness, for Rawls, involves "recognition of and willingness to accept the consequences of the burdens of judgment" (Rawls, 2005, p. 94; see also: pp. 54-58). Setting aside debates over Rawls's own articulation of the burdens of judgment and their consequences for the use of public reason, the basic insight behind this second aspect of reasonableness involves recognizing that those who meet the minimal threshold of recognition respect will not all hold the same comprehensive moral or religious doctrine. The burdens of judgment are meant to explain this idea by showing that there are reasonable explanations for why people may come to hold different views - explanations that do not call into question the intelligence or morality of one's fellow citizens who disagree. What Rawls calls the fact of reasonable pluralism is predicated on the idea that reasonable people (who have met some basic moral threshold) nevertheless disagree about important questions (Rawls, 2005, p. 55). Teaching this basic sentiment should also be a significant part of any civic education designed to prepare children for cooperating with others in our political and civic lives.

The last few years have shown no shortage of attention to the wide range of disagreements that divide contemporary society. Contemporary society is rife with conflict over moral and religious ideals. These conflicts often play out in the political realm, with different groups of individuals attempting to use the political power of the government to secure what they take to be good for people. The problem arises from the deep disagreement between citizens about what constitutes the good life and how the government should support the flourishing of its citizens.

To prepare children to engage in these debates in ways that maintain respect for our fellow citizens, it is crucial that children learn that disagreement - even about significant questions of morality - need not undermine the reasonableness of their fellow citizens. Take abortion as an example. In this debate, different sides of the political spectrum are deeply divided. Each side has a basis in a widely held moral principle and each take their side to be the correct moral view. Unfortunately, many people view their opponents as not just wrong, but evil. Disagreement tends to slide easily into judgments about the moral character - more accurately, the lack thereof - of those who are on the 'wrong side.'

What is needed is a form a civic education that can teach children to respectfully engage with those with whom they disagree. Our political opponents need not be moral enemies. For this, attention to the reasoning behind the contested claims is crucial along with specific attention to the moral principles appealed to by the different parties. In the abortion debate, for example, we see how each side appeals to a perfectly reasonable principle that has a strong independent claim on our moral sentiment regardless of the side we are on. Importantly for our purposes, each basic principle is fundamentally about respecting people as free and equal. The differences lie in the best way to show this respect.

Civic education should teach children to seek out the moral principles underlying disagreements. Children should practice engaging in debates that respect and acknowledge the reasonableness of another's viewpoint, even if each remains committed to her initial view. Seeking to understand the other side may help people learn to see their political opponents as morally decent people. Disagreement need not imply that one's political opponent is an immoral fool. For example, children could be shown how each major religion and moral doctrine contains an interpretation of recognition respect for people. In addition, literature, history, and philosophy all can demonstrate that well motivated people who aim to respect others reasonably hold very different world views. More foundationally, teaching children that all people are entitled to recognition respect for their free and equal status is important for those cases when trying to understand the other side fails. After all, even immoral fools are human beings whose basic moral status qua person should be protected in political life. ${ }^{7}$

\section{Cultivating Reasonableness: Two Challenges}

It may seem odd to turn to Rawlsian ideal theory for progress in a matter of such practical importance in our nonideal world. Rawls's own project falls squarely within ideal theory. Some defenders of Rawls go so far as to suggest that political liberalism is only defensible if we see that the pluralism Rawls aims to accommodate is that which arises within a well-ordered society that already embraces substantial liberal norms (Quong, 2011). What could such a notion teach us in our nonideal world - a world in which patently unreasonable views gain quick traction and we have a president who defies most standards for reasonableness?

First, I think ideal theory plays an important role in establishing a clear metric by which we can judge the ways our nonideal world falls short. Criticizing current practices as unjust and disrespectful implicitly rely on some normative ideal of justice and respect. A clear articulation of these goals is important for justifying our critique of the nonideal world.

Civic education aimed at cultivating reasonable citizens who respect one another as equals despite disagreement should be an important public function of education, even in Rawls's well-ordered society. ${ }^{8}$ The cultivation of civic virtue cannot be taken for granted. This demonstrates a public commitment to ensuring a common basis for the necessary civic virtues that sustain fair political cooperation. Working out what civic education should look like in this ideal context can help us understand the components needed to ensure children learn how to treat others with full recognition respect when they are dealing with those with whom they deeply disagree.

Second, one might wonder whether the gap between the ideal and our current context is too great to make any 
guidance provided by ideal theory helpful. Unreasonable views that reject the equal status of all people are increasingly common in public debate. The current president makes so many racist and sexist statements there is no shortage of examples of public statements that fail to meet even the minimal moral threshold for reasonableness. What are civic educators to do?

Educators can use the contemporary conflicts to demonstrate that disrespecting our fellow citizens undermines the common ties that hold us together. Trump's outright racist and sexist statements draw immediate public outrage and a counter argument reasserting the humanity and equal status of those who he degrades. This conflict and reaction can be an instructive tool to show first-hand accounts of the harm failure to respect our fellow citizens can do to both individuals and our society.

Rather than undermine my proposal, I think the current context in which examples of unreasonableness are easily at hand lends urgency to the goal of teaching the next generation that political cooperation must be founded on recognition respect for the equal status of all. A public civic education that teaches children to be reasonable can serve as a powerful antidote against the influence of parents who seek to inculcate their children with beliefs or practices that undermine the child's ability to respect herself and others as equal.

There are many permissible ways that children can be taught respect for themselves and their fellow citizens as free and equal persons, tracking the many reasonable views that exist in our society. Educators should aim to show this diversity of ways comprehensive doctrines aim to respect people's free and equal status as a way of illustrating both what recognition respect involves and the diversity of ways this is embedded in different citizens' world view.

\section{Conclusion}

If civic education equips children with the skills of reasoning and the central aim of looking for the moral principles underlying our disagreement, society will move a step closer towards the ideal world Rawls envisions. More immediately, in a society so deeply fractured by political divides that we no longer view the other side as having any hold on basic facts and as deeply immoral and misguided, we can perhaps teach children to view others with a kind of empathy and openness that may promise a return to a more integrated political community grounded on a basic recognition respect for all people. ${ }^{9}$

${ }^{1}$ Implicit bias can be just as harmful to developing a respectful democratic citizenry. Recent studies have shown that most people harbour implicit biases favouring white, male, heterosexuals and disadvantaging those who do not fit these norms. These biases affect nearly everyone, including those who defend the importance of free and equal standing for all persons. Yet there are a few promising signs for helping to prevent this kind of bias from forming, particularly when young children are regularly exposed to a people from diverse segments of our society and learn to engage with them on equal terms. See: e.g., Laurie A. Rudman, et al. (2001) and Bigler \& Liben (2007).

${ }^{2}$ To be clear, I am in no way trying to claim that the implicit forms of bias are not a problem. All of these forms of inequality and unequal respect are damaging to our common political and moral community.

3 Darwall distinguishes recognition respect from appraisal respect, which consists in a positive evaluative attitude in recognition of a person engaged in a particular pursuit (Darwall, 2006, p. 122).

${ }^{4}$ Rawlsians will no doubt notice significant departures from Rawls herein. This paper is not intended to be an interpretation of Rawls, rather I hope to be inspired by the general tradition of Rawlsian political liberalism to draw lessons from his approach relevant for our contemporary political challenges.

${ }^{5}$ I have elsewhere argued for a conception of reasonableness that serves as a minimal moral threshold of recognition respect for the basic status of all people as free and equal.

${ }^{6}$ I defended the feminist potential of reconceiving Rawlsian recognition respect as the minimal threshold of reasonableness in my dissertation, Political Liberalism and Its Feminist Potential (2015) and Edenberg (forthcoming). For others who develop different connections between recognition respect and Rawlsian Political Liberalism, see Neufeld (2005), Boettscher (2007 \& 2012), Hartley and Watson (2010), Brake (2013), and Watson and Hartley (forthcoming).

7 The basic status of all persons ought to be protected by political society. How does this apply to protections for unreasonable citizens? Here, I suggest following a similar line of argument as Quong (2011, Chapter 10), who defends the idea that unreasonable citizens still have rights that are respected for all citizens.

${ }^{8}$ I've developed this view elsewhere in Edenberg (2016 and forthcoming). See also Neufeld and Davis (2010) and Costa (2011). 
9 Thanks to Johannes Drerup and Michael Hannon for helpful comments on this paper. Please note that this is a minimally revised version of the original paper published in on_education (date of publication of the revised version: 17.01.2019).

\section{References}

Bigler, R.S. \& Liben, L.S. (2007). Developmental Intergroup Theory: Explaining and Reducing Children's Social Stereotyping and Prejudice. Current Directions in Psychological Science 16 (3), 162-166.

Boettscher, J.W. (2007). Respect, Recognition, and Public Reason. Social Theory and Practice 33, 223-249.

Boettscher, J.W. (2012). The Moral Status of Public Reason. Journal of Political Philosophy 20 (2), 156-177.

Brake, E. (2013). Rereading Rawls on Self-Respect. In R. Abbey (ed.), Feminist Interpretations of Rawls, University Park, PA: The Pennsylvania State University Press, pp. 57-74.

Costa, V. (2011). Rawls, Citizenship, and Education. New York: Routledge.

Darwall, S. (2006). The Second Person Standpoint: Morality, Respect, and Accountability. Cambridge, MA: Harvard University Press.

Edenberg, E. (2016). Civic Education: Political or Comprehensive? In J. Drerup et al. (eds.), Justice, Education and the Politics of Childhood: Challenges and Perspectives (187-206). Dordrecht: Springer International Publishing.

Edenberg, E. (forthcoming). Growing Up Sexist: Challenges to Rawlsian Stability. Law and Philosophy (doi.org/10.1007/s10982-017-9325-1)

Hartley, C. and Watson, L. (2010). Is Feminist Political Liberalism Possible? Journal of Ethics \& Social Philosophy 5 (1), 121.

Neufeld, B. (2005). Civic respect, political liberalism, and non-liberal societies. Politics, Philosophy \& Economics 4 (3), 275299.

Neufeld, B. and Davis, G. (2010). Civic Respect, Civic Education, and the Family. Educational Philosophy and Theory 42 (1), 94-111.

Neufeld, B. (2013). Political Liberalism and Citizenship Education. Philosophy Compass 8(9), 781-797.

Quong, J. (2011). Liberalism without Perfection. Oxford: Oxford University Press.

Rawls, J. (2005). Political Liberalism: Expanded Edition. New York: Columbia University Press.

Rudman, L.A. et al. (2001). Unlearning Automatic Biases: The Malleability of Implicit Prejudice and Stereotypes. Journal of Personality and Social Psychology 81 (5), 856-868.

Watson, L. and Hartley, C. (forthcoming). Equal Citizenship and Public Reason: A Feminist Political Liberalism. New York: Oxford University Press.

\section{Recommended Citation}

Edenberg, E. (2018). Cultivating Reasonableness in Future Citizens. On Education. Journal for Research and Debate, 1 (1). doi: 10.17899/on_ed.2018.1.8

\section{About the Author}

Elizabeth Edenberg is Senior Ethicist for Ethics Lab at Georgetown University's Kennedy Institute of Ethics, specializing in Political Philosophy, Ethics, and Feminist Philosophy. 